\title{
3. Telework and its effects in the United States
}

\section{Kate Lister and Tom Harnish}

\section{EXECUTIVE SUMMARY}

Desks in the United States of America (US) are empty an average of 40-50 percent of normal working hours. When employees are not in their office, they are working in conference rooms, in clients' offices, at coffee shops, at home, in their cars, at airports and just about anywhere there is an Internet connection. They are working in those places at all times of the day - during normal working hours, at nights and on weekends.

While only 19.7 percent of the US workforce teleworks on a regular basis (at least once a week), many other US workers telework from remote locations with information and communications technologies (ICTs) or telecommute (defined as avoiding commuter travel through the use of technology) less regularly. While details about where, when and how often employees do so are largely unavailable, estimates suggest that approximately 40 percent telework at least occasionally. ${ }^{1}$ When they do, they use a wide variety of ICTs, including, for example, the Internet, smartphones, home computers, laptops, tablet computers, teleconferencing and videoconferencing.

While many acknowledge there are negative aspects to telework/ telecommuting, in particular the tendency to work longer hours, the large majority of US employees (79-87 percent, depending on the sector) say they would like to work remotely at least some of the time. A number of studies also show that more than a third of them would give up some pay for the opportunity to telework.

Based on an extensive examination of academic and other research, this chapter concludes that the majority of US workers feel that the benefits of technology - and its impact on how, when and where they can work - outweigh the frustration that sometimes accompanies its use. For example, over three-quarters of US employees say that their ability to use technology outside of normal working hours is a positive development. Although the feeling of being 'always on' is frequently cited as a negative, 
it is mitigated by the benefits, such as reduced work-life conflict, increased autonomy, feeling trusted and empowered, and avoiding commuter travel.

While working in an office still represents the norm, telework is now common across age groups, gender, occupation, education levels and income levels. The trend is growing, as evidenced by dramatically reduced office occupancy and a more than 100 percent increase in regular telework (at least one day per week) since 2005.

Assessing the impact of technology on workers is difficult for a variety of reasons. First, there is no national or even regional source of data on where and when US employees work. Some employers track it to the limited extent that they can, but such company data is rarely shared. Second, the trend toward workplace flexibility - allowing employees to work where and when they like, for example - further muddies the concept of the traditional workday. Is an employee who answers an email at 9 p.m. working overtime or just blending work and non-work outside of normal hours? Third, the use of technology is ubiquitous; over 90 percent of US employees are Internet users. There is therefore no way of comparing ICT users with those who do not use such technology.

Technology has clearly changed the nature of both work and workers, for good and for bad. This genie is probably not going back into the bottle. What we need now is a better understanding of how telework impacts people and organizations, so that we can develop work practices, policies and governance that maximize its benefits and minimize its potential for negative impacts. The research shows that with appropriate policies, practices, training and cultural integration, organizations can maximize the employer, employee and environmental benefits of telework.

\section{INTRODUCTION}

Seventy-nine percent of US private sector employees and 87 percent of federal workers say they would like to telework/telecommute at least some of the time. ${ }^{2}$ Over half of US workers have jobs that are compatible with telework, but it is still generally considered to be a privilege reserved for older, more tenured employees rather than a mainstream trend. ${ }^{3}$ While 38 percent of US employers allow some employees to telecommute on a regular basis, only 8 percent offer this option to all employees (see Figure 3.1). ${ }^{4}$ Nonetheless, the trend is growing.

Approximately 3.7 million US employees telecommute half-time or more ( 2.5 percent of the employee workforce). That number grew by 103 percent between 2005 and 2014. ${ }^{5}$ The percentage of employers that allowed 


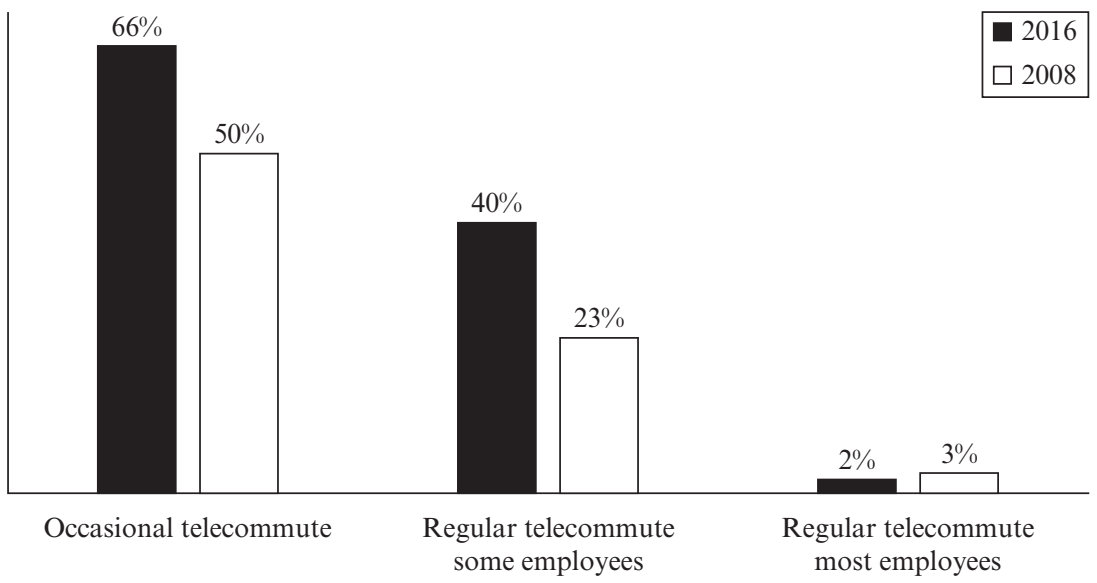

Figure 3.1 US employers who allow telecommuting

regular telecommuting for some or all employees has also been growing (see Figure 3.1).

While saving money, primarily through real-estate cost reductions, became the primary driver for increased telework during the 2007-09 recession, it is increasingly being used as part of a holistic strategy aimed at:

- enhancing employee attraction and retention;

- reducing work-life conflict;

- increasing productivity;

- improving sustainability/ensuring continuity of operations;

- reducing traffic congestion;

- reducing pollution;

- accommodating the disabled; and

- slowing the outbound migration of talent.

Nevertheless, in spite of the known benefits for people, planet and profit, resistance from senior leaders and middle managers continues. Mistrust, the attitude that if left untethered, employees will not work as hard, is common. Research shows that teleworkers often work harder than their office-bound cohorts, primarily because they give back some of the time they would have otherwise spent commuting, and because they enjoy the privilege of working remotely and do not want to lose it.

The impact of the conflicting effects of telework/telecommuting is the primary focus of the analysis in this chapter. 


\section{METHODOLOGY AND MAIN DATA SOURCES}

A wide range of research sources are cited in this chapter, but the majority of the data used to assess the effects of telework/mobile work on working time, work-life balance, performance, and health and well-being came from:

- the American Community Survey (ACS);

- the US General Social Survey (GSS);

- the Ipsos Global Telecommuting Survey (Ipsos);

- the Federal Employee Viewpoint Survey (FEVS); and

- the American Time Use Survey.

Important details and caveats about each data source are provided below.

\section{American Community Survey}

The most robust data on telework in the US is gathered annually from the ACS, ${ }^{6}$ a product of the US Census Bureau. Unfortunately, the ACS tracks the incidence of telework based on a single question: 'What was your primary means of transportation to work during the survey week?' One of the answers is 'worked at home'. Thus, the only thing we know about these respondents is that they worked at home at least half the time. We cannot ascertain from this source the number of employees who work away from the office, but not at home. There is no longitudinal data collected by the US Census Bureau or any other organization regarding employees who work in third places, such as a customer's office, on the road, in coffee shops or at co-working spaces.

Self-employed workers (whether incorporated or unincorporated) were excluded from the ACS data used in this report, although they are often included in the telework numbers reported by US government agencies and the media.

\section{General Social Survey ${ }^{7}$}

The $\mathrm{GSS}^{8}$ is a biannual, nationally representative survey and personal interview of US households conducted by the National Opinion Research Center (NORC), federally funded by the US National Science Foundation. The survey includes a Quality of Worklife (QWL) module that comprises 76 questions developed by a group headed by the US National Institute of Occupational Safety and Health (NIOSH). Data from these surveys represents all employed people, including the self-employed, contractors and temporary workers. 


\section{Ipsos}

Ipsos is one of the world's leading market research firms. They conduct a monthly omnibus survey in 24 countries. In 2011, an Ipsos survey included questions about telecommuting. The resulting report, 'Telecommuting: citizens in 24 countries assess working remotely for a total global perspective', ${ }^{9}$ drew on an employee population from a screened sub-group of an international sample of 18682 adults aged 18-64 years in the US and Canada (and aged 16-64 years in all other countries as well). Weighting was applied to ensure a representative sample with a margin of error of plus or minus 3.1 percentage points. There has been no update to the 2011 report.

\section{Gallup, Inc.}

Gallup, Inc., purports to own the largest database in the world on management. Their Gallup Panel, Gallup Daily tracking, and Gallup's employee engagement database collectively represent the study of nearly 200000 global employees. Much of the data regarding worker hours, the frequency of telecommuting and worker attitudes was derived from their reports. Some of their survey questions are parsed to exclude the self-employed, but not all. It is therefore important to read the notes associated with each mention of the data derived from this source.

\section{Federal Employee Viewpoint Survey}

The FEVS ${ }^{10}$ is a survey conducted annually by the US Office of Personnel Management. It includes all full-time and part-time permanent nonseasonal US federal employees including federal teleworkers. It is used as a tool for gauging employee attitudes. Over 90 percent of federal employees (nearly 400000 individuals) completed the survey in 2013 (which was reported in 2014).

\section{American Time Use Survey}

The US Bureau of Labor Statistics conducts the annual ATUS. ${ }^{11}$ It measures the amount of time people spend doing various activities, such as paid work, commuting, childcare, volunteering and socializing.

The ATUS offers measures of telework that are derived from data recorded in the diary section of the ATUS by respondents. In their diary, individuals report what they were doing over a 24 -hour period and where they were for most activities. 
The ATUS does not include any specific questions about work schedules or formal arrangements to work from home, so it is impossible to know whether a survey respondent who reported working from home was doing so on a scheduled office day, was working in addition to usual work hours, or whether the respondent regularly or usually worked from home.

American Time Use Survey data includes people who are employed, unemployed or non-employed; full-time and part-time workers, including independent contractors and freelancers; and unincorporated and incorporated small business employees/owners.

\section{WORKPLACE FLEXIBILITY IN THE UNITED STATES}

Workplace flexibility has very negative connotations in many parts of the world, especially Europe where it means that employers circumvent working-time laws and regulations to force workers to work whenever employers want them to do so. In the US, however, flexibility means giving workers options regarding where, when and how they work, and this type of worker-orientated flexibility is one of the most sought after benefits among US workers.

Worker-orientated workplace flexibility in the US is offered in a variety of forms including telework - which is defined in this volume as using ICTs to perform work from outside the employer's premises, but also other forms such as flexible hours (that is, formal and informal flexi-time arrangements), flexible days, and so on. It should be noted that telecommuting is a subset of telework that involves the substitution of ICTs for commuting. ${ }^{12}$

\section{The Desire for Workplace Flexibility}

A 2015 study by Ernst \& Young revealed that, after competitive pay and benefits, the top factors employees say are very important in a potential job are 'being able to work flexibly and still be on track for promotion' which was tied at 74 percent with 'working with colleagues, including my boss, who support my efforts to work flexibly'. ${ }^{13}$

WorldatWork finds flexible scheduling the second most commonly utilized employee health and well-being benefit (after physical health risk assessments). ${ }^{14}$ Their research shows having access to workplace flexibility, regardless of whether employees use it, has a positive impact on job satisfaction.

Accenture's 2013 research indicated 80 percent of respondents agreed that having flexibility in their work schedule was extremely or very 
important to work-life balance, yet 70 percent said technology brings work into their personal lives. ${ }^{15}$

Worker-orientated workplace flexibility is ranked at the top or near the top of the list of most important factors in a job. Millennials in particular find it highly attractive. ${ }^{16}$

Finally, peer-reviewed research by economist Lonnie Golden of Penn State University suggests the extent to which work-life conflict occurs is dependent on not just the number of hours an employee works, but whether or not they feel they have discretion over the timing of their working hours and schedules. ${ }^{17}$

\section{TELEWORK IN THE US}

Research by Pew Research Center indicates that 94 percent of employed Americans are Internet users. ${ }^{18}$ There is no US source of information on the use of ICTs among the work-at-home population. We assumed for this chapter that all work at home involves the use of ICTs, and we assumed that telework/mobile work may not, strictly speaking, be work from home but could also potentially be in third spaces such as coffee shops, libraries, in airports, on aircraft or at co-working facilities. Unless noted otherwise, those assumptions apply throughout this chapter.

A distinction between telework - the substitution of technology for travel - and telecommuting - the substitution of technology for commuter travel - is made throughout this chapter. However, in general, there is no official count of all teleworkers; therefore, most of the data in this report relates to telecommuters.

The large majority of US employees say they would like to telework at least part of the time:

- 78 percent of US workers and 87 percent of federal workers say they would like to telework all or some of the time. ${ }^{19,} 20$

- 70 percent of parents and 59 percent of non-parents say lack of workplace flexibility, including no option to telecommute, would cause them to seriously consider leaving a job. ${ }^{21}$

\section{Overall Incidence and Place(s) of Work}

Numbers on the overall incidence and place of work differ by source (details below). Taken together, the research suggests the range of telecommute participation levels indicated in Table 3.1.

Based on a special analysis and tabulation of 2014 ACS data conducted 
Table 3.1 Frequency of telecommuting

\begin{tabular}{lc}
\hline Frequency & Participation (\% of US employees) \\
\hline 2.5 to 5 days a week & $2.5-4.0$ \\
1 to 2.5 days a week & $6.0-10.0$ \\
Occasional monthly & $4.0-5.0$ \\
Infrequently & $6.0-11.0$ \\
Never & $60.0-71.0$ \\
\hline
\end{tabular}

Source: Based on American Community Survey 2014 data which is based on analysis of American Community Survey 2015 data by Global Workplace Analytics.

by the authors of this study, 2.5 percent of the US full-time civilian workforce (not including the self-employed) worked away from their employer's workplace half the time or more (3.7 million employees).

United States General Social Survey 2014 data (which includes the selfemployed) indicates that 40 percent of the workforce works from home at least some of the time: 15 percent do so once a month or less, 19 percent do so once a week or less and 6 percent do so full-time. ${ }^{22}$ There is little difference in the frequency of work from home by gender, according to the GSS.

According to the FEVS, ${ }^{23} 29$ percent of all federal employees telecommute. Nearly half of federal telecommuters do so one day a week or more. There is a linear relationship between agency tenure and telework; those with the longer tenure represent the largest group of telecommuters. ${ }^{24}$

The frequency of telework is also increasing. Gallup's most recent survey shows a full 31 percent of employees spend at least some of their time working in a different location than their co-workers, an increase of seven percentage points since 2013. During the same period, the percentage who worked remotely one day a week or less fell nine percentage points (see Figure 3.2), presumably because many have become more frequent teleworkers. While the teleworkers included in Gallup's numbers are not all telecommuters (because they may not be working remotely for a full day), nevertheless they are dealing with many of the same issues.

\section{Incidence by Demographics}

\section{Sex}

Fifty-two percent of employees who work from home half the time or more are women (compared with 47 percent of the total workforce). The ratio of male/female participation has changed little over the past decade. ${ }^{25}$ 

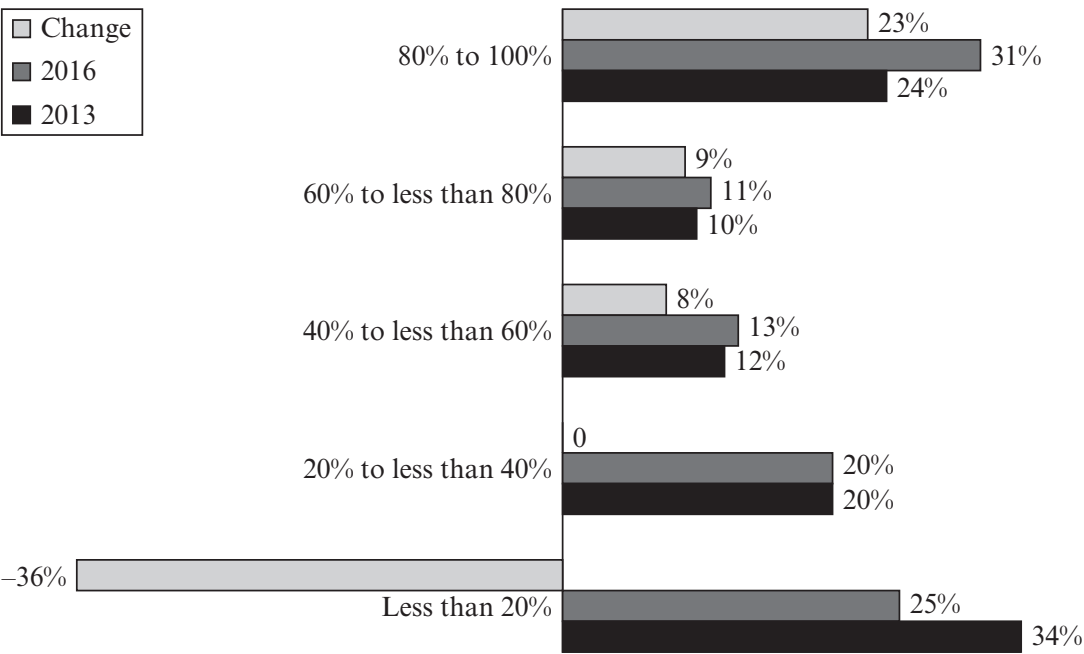

Source: 'America's coming workplace: home alone', March 2017, accessed 10 April 2017 at www.Gallup.com.

Figure 3.2 Time employees spend working remotely

Age

Half of telecommuters are aged 45 years or over, compared with 41 percent of the overall workforce (see Figure 3.3). The greatest disproportional participation in telecommuting is among those aged 65 years and older. ${ }^{26}$

\section{Industry}

The professional services industry accounts for the largest share of telecommuters (17 percent of total) followed by the healthcare and finance industries, which account for 12 percent and 10 percent respectively (see Figure 3.4). ${ }^{27}$

Relative to the total workforce, telecommuting is disproportionately more prevalent in the industries in Table 3.2. ${ }^{28}$

\section{Occupation}

Telecommuting is most common among managers, salespeople and administrative workers; see Table 3.3. ${ }^{29}$

\section{Education}

Telecommuters are, on average, more highly educated than other employees. Approximately 53 percent have at least a bachelor's degree, compared with 37 percent of non-telecommuters. ${ }^{30}$ 


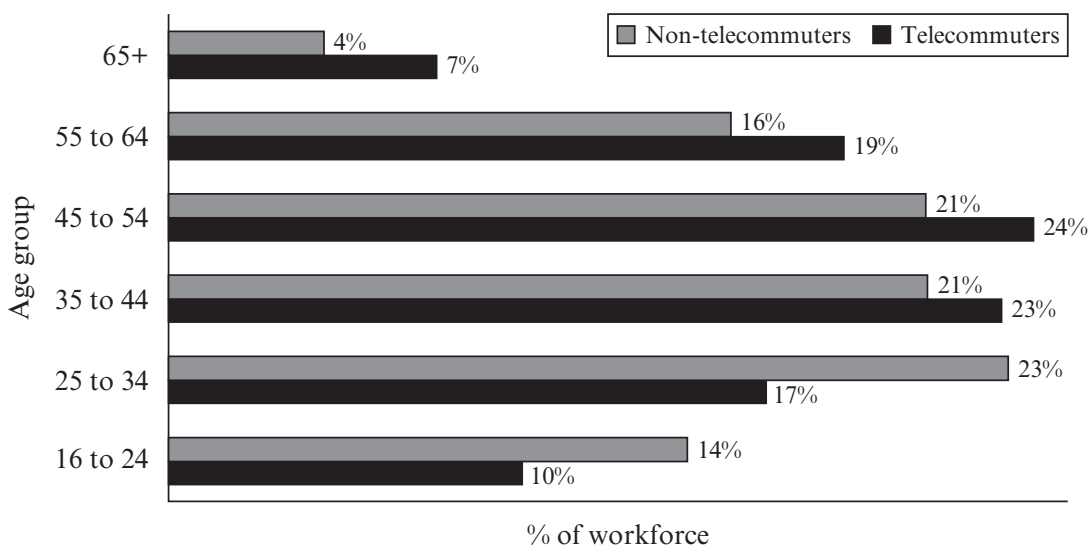

Source: Global Analytics analysis of US American Community Survey, 2015, US Census Bureau.

Figure 3.3 Telecommuter vs. non-telecommuter by age

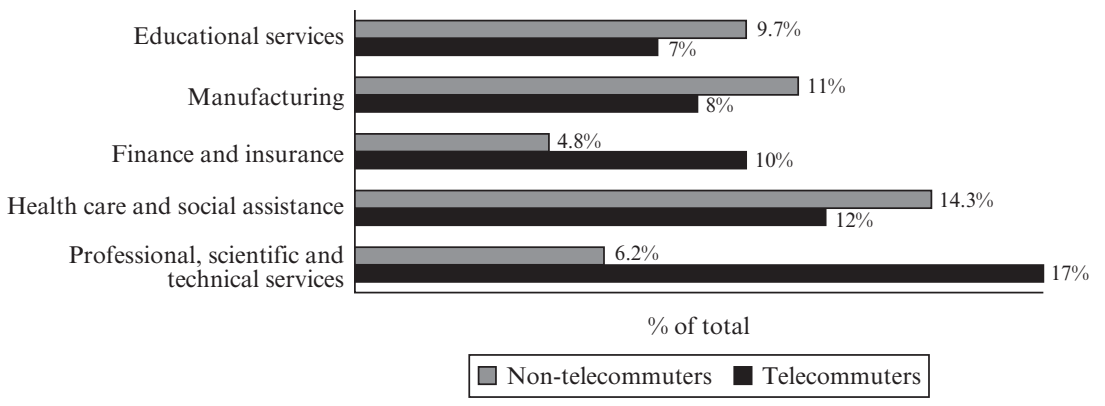

Source: Global Analytics analysis of US American Community Survey, 2015, US Census Bureau.

\section{Figure 3.4 Telecommuters versus non-telecommuters by industry}

However, not all work-from-home jobs require a college degree. Twenty percent of teleworkers have a high school diploma (or less), and 27 percent have an associate's degree.

\section{Income}

Telecommuters earn, on average, more than non-telecommuters. Among those who earn $\$ 100000$ a year or less (79 percent of telecommuters compared with 67 percent of non-telecommuters), the average telecommuter 
Table 3.2 Disproportionate prevalence of telecommuting by industry

\begin{tabular}{lc}
\hline Industry & Relative prevalence \\
\hline Professional services & $2.8 \mathrm{x}$ \\
Information & $2.2 \mathrm{x}$ \\
Finance & $2.0 \mathrm{x}$ \\
Real estate and leasing & $1.9 \mathrm{x}$ \\
\hline
\end{tabular}

Source: Based on American Community Survey 2015 data by Global Workplace Analytics.
Table 3.3 Percentage of telecommuting and non-telecommuting by industry

\begin{tabular}{lcc}
\hline Occupation & \% of telecommuters & $\%$ of workforce \\
\hline Management & 18 & 10 \\
Sales and related & 13 & 11 \\
Office and administrative support & 10 & 13 \\
Business and financial & 9 & 5 \\
Personal care and service & 8 & 4 \\
\hline
\end{tabular}

Source: Based on American Community Survey 2015 data by Global Workplace Analytics.

\section{Table 3.4 Cities with the highest and lowest percentage of telecommuters}

\begin{tabular}{lc}
\hline City/state & $\%$ employees who telework half time or more \\
\hline Boulder, CO & 8.5 \\
Lafayette, LA & 1.0 \\
\hline
\end{tabular}

Source: Based on American Community Survey 2015 data by Global Workplace Analytics.

makes approximately $\$ 4000$ a year more than non-telecommuters $(\$ 41705$ compared with $\$ 37657$, respectively). ${ }^{31}$

\section{Location}

The percentage of telecommuters varies widely by location. ${ }^{32}$ The highest and lowest percentage are shown in Table 3.4.

See Table 3.5 for the cities with the largest growth in the trend among workers.

The differences are probably related to the composition of jobs in particular areas and, to a lesser extent, a region's telework advocacy. 
Table 3.5 Cities with the largest growth in the percentage of telecommuters

\begin{tabular}{lc}
\hline City/state & $\%$ increase 2005 to 2015 \\
\hline Chattanooga, TN & 325 \\
Bremerton, WA & 273 \\
Youngstown, OH & 246 \\
\hline
\end{tabular}

Source: Based on American Community Survey 2015 data by Global Workplace Analytics.

\section{Formal versus Informal Telework Policies among US Employers}

Approximately 29 percent of employers had a formal telework policy in place as of 2013, a decline from 35 percent in 2009. ${ }^{33}$ This decline is probably the result of the following:

- Employers not wanting to publicize their program for fear everyone would want to telework; most, for example, do not include telework availability in recruitment materials.

- Ambiguity over taxation, labor law and other regulations that apply to where and when people work. For example: (1) state and regional employee and employer taxes may be triggered when individuals work outside their own region for even a brief period; (2) additional employer licensing and registration may be required by some locales; and (3) different overtime, safety, and other labor laws may apply when an employee is working in a different region. All of this represents an administrative burden as well as potential penalties for non-compliance.

- Wanting to allow sub-groups the freedom and flexibility to craft their own policies. For example, about 15 percent of employers either have or plan to formalize telework policies at the sub-group level, although this practice has declined since 2011 when it accounted for about 27 percent of employers.

\section{EFFECTS OF TELEWORK/MOBILE WORK}

\section{Effects on Working Time}

While the data about working time in the US varies by source, there appears to be a consensus that: ${ }^{34}$ 
- US workers worked longer hours in 2014 than in 2007, but fewer than in 2002;

- men work longer hours than women, and the number of hours they work has grown faster than for women;

- men are working a majority of their extra hours at home while women are largely substituting office hours with from home work hours;

- the majority of those who work in excess of both 50 and 60 hours a week never work from home;

- the primary reason for working from home is to catch up on work; and

- among those who work from home some or all of the time, those who do so one to four days a week work the longest hours.

The details behind these findings are given next.

The most robust data on working hours in the US is generated annually by the ATUS, ${ }^{35}$ a product of the US Bureau of Labor Statistics. As noted earlier, the ATUS does not make a distinction between people who work from home to catch up on work (that is, overtime work) or those who work at home as a substitution for commuter travel. The ATUS also does not distinguish between people who work in the evenings and on weekends as part of their normal schedule and those who do so in addition to their normal workweek.

In spite of those limitations, ATUS data can be useful in understanding working hours for the purpose of this report. According to ATUS data:

- Employees work, on average, between 37 hours (service industry workers) and 49 hours (farming, fishing and forestry workers) per week.

- Men work an average of 44.25 hours a week, women 40.95 hours a week.

- Between 2007 and 2014, this number increased by one hour a week for men and six minutes a week for women.

- The largest increases occurred among those with college degrees (but not advanced degrees), the middle two income classes, and transportation and production workers.

The 2014 ATUS data indicates that among those who worked from home on an average day:

- Men did so an average of 3.5 hours per day and women did so an average of 3.04 hours per day. This represents an increase of 37 minutes a day for men and five minutes a day for women from 2007. 
- In terms of work at their workplace, men who worked at their workplace typically worked an average of 8.52 hours a day while women worked an average of 7.96 hours per day. Those numbers represent an increase of ten minutes a day for men, and a decrease of 7 minutes a day for women when compared to the 2007 numbers.

- On the whole, therefore, 78 percent of the increase in working hours from 2007 to 2014 for men is time working from home rather than in the office. Women, however, seem to be substituting time at work with time working from home.

Since ATUS numbers do not distinguish between single jobholders, multiple jobholders or the self-employed, it is not known whether the increase in work represents a trend or is a reflection of extra work taken on during the recession.

The 2014 GSS Survey (which includes the self-employed) indicates the primary reason cited for working from home (by 41 percent) was 'to catch up on work'. This figure grew eight percentage points between 2002 and 2006, but negligibly between 2010 and 2014. Other reasons for working from home included: 'part of primary job' (29 percent in 2014), 'operating a home-based business' (17 percent in 2014) and 'other combinations and other reasons' (14 percent in 2014).

Among GSS respondents who reported working between 50 and 59 hours during the survey week, 53 percent never worked from home, 17 percent worked from home once a month or less, 30 percent did so one to four days a week, and 6 percent mainly worked at home. A similar distribution was seen among those who reported working more than 60 hours a week; those who never worked at home accounted for the largest portion (44 percent), and those who worked at home one to four days a week accounted for the second largest portion (34 percent).

The number of days per month respondents reported working extra hours (over 40 hours a week) ranged from a low of 4.4 days a month for those who never worked from home, to nine days a month for those who worked at home one to four days a week.

\section{Use of ICTs for after-hours working (supplemental telework)}

Thirty-six percent of US employees, including both telecommuters and office-based workers, say they frequently check their email outside of normal business hours (see Figure 3.5). ${ }^{36}$

More than half of the employees surveyed (52 percent) say they feel that checking email outside of normal working hours is at least somewhat necessary to get ahead in the organization (see Figure 3.6). 


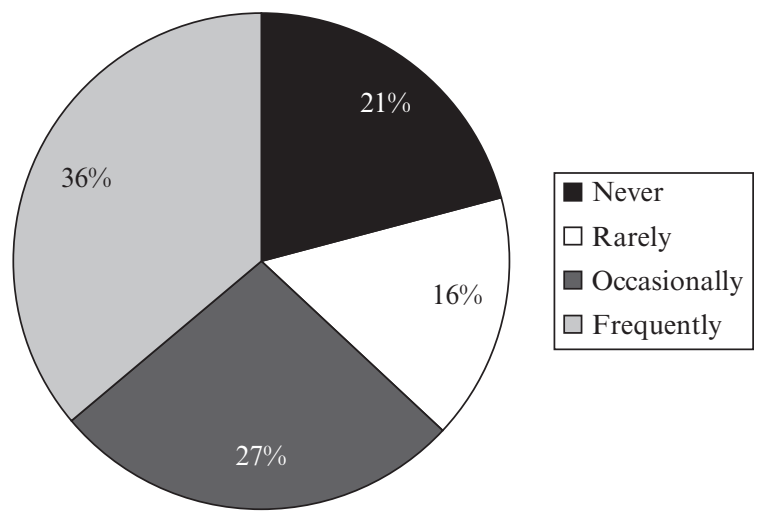

Note: Asked of people who said they use email at work.

Source: Gallup, Inc. (March 2017).

Figure 3.5 How often do you check your email outside of working hours?

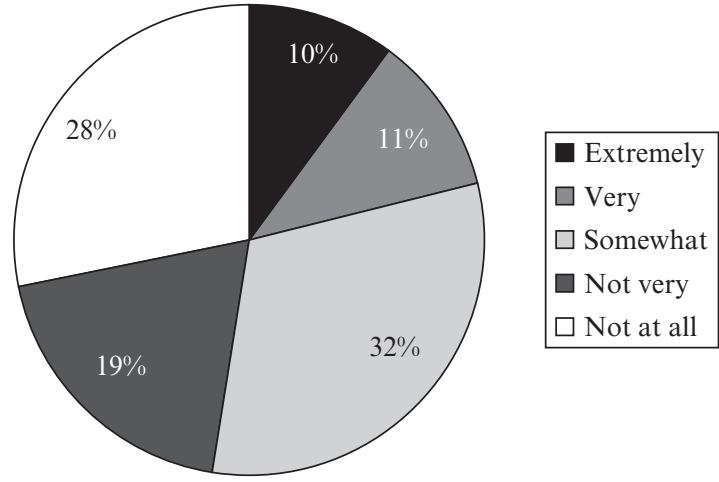

Note: Asked of people who said they use email at work.

Source: Gallup, Inc. (March 2017).

Figure 3.6 How important do you feel checking email outside of regular hours is to your career?

Nine out of ten say they feel the number of emails they respond to outside of normal hours is reasonable (see Figure 3.7).

While Gallup has not asked the same question about after-hours computer use since 2014, at least at the time the sentiment was similar 


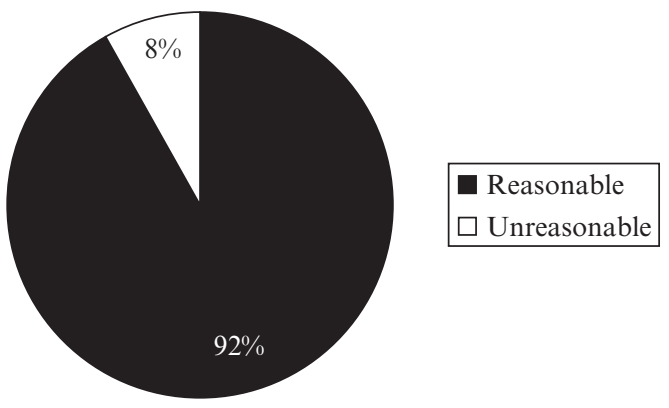

Note: Asked of people who said they use email at work.

Source: Gallup, Inc. (March 2017).

Figure 3.7 Is the amount of emails you have to check after business hours reasonable?

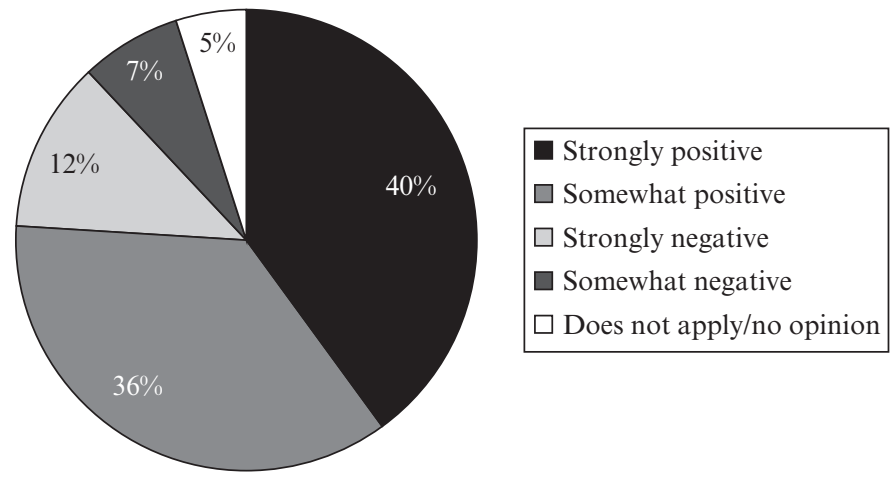

Source: Work and Workplace, Gallup, Inc., 2014.

Figure 3.8 Attitudes toward after-hours ICT use

with more than two-thirds of respondents saying that being able to work remotely outside of normal business hours was generally positive (see Figure 3.8). ${ }^{37}$

However, six in ten employees say they would favor a law to limit email and other digital communication after normal business hours (see Figure 3.9). Perhaps the seeming dichotomy could be explained by the removal of guilt if working after hours was shunned by society and because, presumably, their colleagues would similarly not be working after hours.

Gallup also cautions employers to avoid acting prematurely on policies 


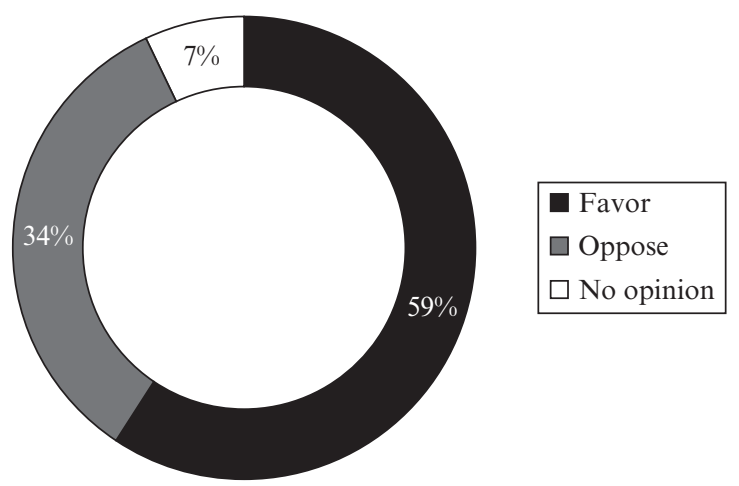

Note: Asked of employed adults.

Source: Gallup, Inc. (March 2017).

Figure 3.9 Would you favor or oppose a labor law that gave employees the 'right to disconnect'?

regarding the use of technology outside of normal working hours. ${ }^{38}$ Their research also finds the more engaged employees are, the less likely they are to experience stress regardless of whether or not they are expected to check email after hours. ${ }^{39}$

- Thirty-four percent of engaged employees whose employer expected them to check after-hours emails and 30 percent of those whose employers did not expect them to do so reported stress the previous day.

- By contrast, 54 percent of employees who were not engaged and 56 percent of those disengaged whose employers expected them to check emails after hours reported stress.

Among those whose employer did not expect their employees to check emails after hours, 39 percent of those not engaged and 53 percent of those disengaged reported stress the prior day.

According to Gallup, younger employees tend to approach work and life as more of a blend than separate parts of their lives. Table 3.6 shows just how interspersed life is for this group.

\section{Effects of Telework on Individuals}

Table 3.7 summarizes the most common effects of telework on individual or job performance in the US, and the extent to which their effects on 
Table 3.6 Percentage of younger employees who do the following activities

\begin{tabular}{ll}
\hline At work & At home \\
\hline $60 \%$ check or send personal emails & $51 \%$ check or send work emails \\
$57 \%$ send personal text messages & $43 \%$ send work related texts \\
$53 \%$ make personal phone calls & $46 \%$ make work-related phone calls \\
$50 \%$ check or use social media & $34 \%$ conduct work-related research \\
\hline
\end{tabular}

performance are typically positive, neutral, and/or negative. The effects presented in this section have been derived from a wide range of studies that have been catalogued by the authors of this report and from the authors' own client work. ${ }^{40}$ Subgroup data is not available. Please refer to the notes following Table 3.7 for additional details.

\section{Effects of Telework on Organizational Outcomes}

A wide range of research indicates that when employees are given control over where, when and how they work, the majority of them are happier, healthier, experience less work-life conflict and stress, and report greater well-being. $41,42,43,44,45$

As the studies cited in the above paragraph demonstrate, when telework is properly implemented, it translates into the following organizational benefits: 46

- reduced sickness, primarily owing to less exposure to sick co-workers, greater autonomy, reduced stress, access to healthier food, reduced commuting, better sleep, being able to recuperate from injury or illness in the comfort of home and having more time for exercise;

- reduced stress, primarily owing to greater autonomy, reduced worklife/life-work conflict, reduced exposure to office politics, having clear goals and being measured by results;

- reduced work-life/life-work conflict and burnout, primarily owing to having control over their hours and place of work, being able to better integrate personal and work responsibilities, and being able to spend more time near loved ones;

- reduced presenteeism, ${ }^{47}$ primarily owing to: better health, greater sense of control, higher job satisfaction and greater engagement;

- improved sleep, primarily owing to reduced stress and more time owing to lack of commute;

- increased job satisfaction, engagement and sense of achievement, primarily owing to: greater autonomy, feeling trusted, greater control 


\section{Table 3.7 Selected effects of telework on individual job performance- related factors}

\begin{tabular}{|c|c|c|c|c|}
\hline Effect & Positive & Neutral & Negative & Notes \\
\hline Autonomy & $\mathrm{x}$ & & & \\
\hline Belongingness & & $\mathrm{x}$ & $\mathrm{x}$ & 1 \\
\hline Work-life/life-work conflict & $\mathrm{x}$ & $\mathrm{x}$ & $\mathrm{x}$ & 2 \\
\hline Productivity & $\mathrm{x}$ & & & \\
\hline Concentration & $\mathrm{x}$ & & & \\
\hline Collaboration & $\mathrm{x}$ & & $\mathrm{x}$ & 3 \\
\hline Communication & $\mathrm{x}$ & & $\mathrm{x}$ & 3 \\
\hline Trust & $\mathrm{x}$ & & $\mathrm{x}$ & 4 \\
\hline Job satisfaction & $\mathrm{x}$ & & & \\
\hline Engagement & $\mathrm{x}$ & & & \\
\hline Happiness & $\mathrm{x}$ & & & \\
\hline Health & $\mathrm{x}$ & & $\mathrm{x}$ & 5 \\
\hline Goal clarity & $\mathrm{x}$ & & & \\
\hline Role clarity & $\mathrm{x}$ & & $\mathrm{x}$ & 6 \\
\hline Advancement & & $\mathrm{x}$ & $\mathrm{x}$ & \\
\hline Cultural attachment & & $\mathrm{x}$ & $\mathrm{x}$ & 7 \\
\hline Stress & $\mathrm{x}$ & & $\mathrm{x}$ & 8 \\
\hline Commute stress & $\mathrm{x}$ & & & \\
\hline Time & $\mathrm{x}$ & $\mathrm{x}$ & & \\
\hline Money & $\mathrm{x}$ & & & \\
\hline Family & $\mathrm{x}$ & $\mathrm{x}$ & $\mathrm{x}$ & 9 \\
\hline Childcare & $\mathrm{x}$ & & $\mathrm{x}$ & 10 \\
\hline Eldercare & $\mathrm{x}$ & & & \\
\hline
\end{tabular}

Notes:

1. Unless efforts are made to ensure that teleworkers are treated the same as nonteleworkers, the former may begin to feel disenfranchised. Examples of how to avoid this include: (1) mixing their time between office and remote work; (2) using technology such as an Intranet or video-conferencing to reinforce bonds with colleagues and help them feel virtually there; (3) having places for them to work when they do come to the office; (4) holding virtual events that everyone participates in; (5) using inclusive etiquette when virtual participants are present; and (6) having supportive co-workers, managers and senior leaders.

2. While the majority of research shows that telework reduces work-life and life-work conflict, it should be noted that at least one study suggests that role ambiguity can increase conflict. The study indicates that while autonomy can mitigate this conflict, it is largely the result of isolation and information undersupply. ${ }^{48}$

3. Some teleworkers feel that they communicate and collaborate better when they work remotely. Specifically, they find they are better able to include distant team members in their work. Success factors include having and knowing how to use collaboration tools, training for both on-site and off-site workers, and choosing the right people to telework. Absent these factors, collaboration can suffer.

4. Managers are often mistrustful of teleworkers. Out of sight, they assume teleworkers are slacking off. Successful managers learn to manage their people based on what people do, not where, when, and how they do it. Telework does not work unless there is trust between not just managers and employees, but also among co-workers. 


\section{Table 3.7 (continued)}

5. Many teleworkers report getting more sleep and having more time for exercise (owing to the reduction in commuting time), access to healthier food, and reduced stress. These and other factors can lead to better health. However, when problems that arise from telework are left unchecked, it can lead to greater stress and poorer health. In addition, it is critical that ergonomic and safety issues at the remote location be addressed to reduce the chance of injury.

6. While goal clarity typically improves through telework, role clarity can sometimes suffer owing to having fewer borders between work and home life. This can be avoided with training for both on-site and off-site workers; setting clear expectations around working hours and availability; and creating artificial borders to signify the end of the workday.

7. The organization's virtual presence must exude and reinforce its culture if remote employees are to feel that they are a part of it.

8. The majority of remote employees report lower stress, however, some experience stress due to isolation and lack of communications. Autonomy is an important factor in mitigating this stress. This is covered in more depth later in this chapter.

9. Most remote employees report family stress is reduced with telework, but boundaries must be established both within the family, among friends, and between the employee and the organization.

10. In general, telework is not an adequate substitute for childcare for US employees with young children.

over time, better understanding of and connection to organizational goals, and being able to work in the comfort of one's home;

- increased exercise primarily due to: reduced work-life/life-work conflict, and reduced commuting; and

- greater resilience primarily owing to increased flexibility, reduced stress, choice over environment, feeling empowered and better sleep.

\section{Federal telework: a case study on organizational outcomes}

The US Federal Government represents a large and well-studied population of teleworkers. The most recent survey results from this population were made available in $2014 . .^{49}$ According to that survey, approximately 31 percent of federal workers teleworked at least part of the time and only 13 percent chose not to telework at all.

Surveys by the US Federal Government of federal employee views (FEVS) indicate the employee engagement among their teleworkers has been seven to eight percentage points higher than non-teleworkers in all years since 2011. ${ }^{50}$

In addition, the 2013 US Federal Government employee telework survey showed that, compared to those federal government employees who were not allowed to telework, federal teleworkers were: ${ }^{51}$

- 12 percentage points more likely to feel their supervisor supports their need to balance work and life issues ( 85 percent versus 73 percent) and half as likely to report their supervisor did not; 
- 11 percentage points more likely to say they trust and have confidence in their supervisor ( 73 percent versus 62 percent);

- three percentage points more likely to say they know what is expected of them in their job (81 percent versus 79 percent);

- nine percentage points more likely to say that they feel a sense of personal empowerment in their job (50 percent versus 41 percent);

- nine percentage points more likely to recommend their organization as a 'good place to work' than those not allowed to telework (72 percent versus 63 percent);

- eight percentage points more likely to report satisfaction with their jobs (73 percent versus 65 percent);

- five percentage points less likely to report job dissatisfaction (12 percent versus 17 percent);

- eight percentage points less likely to report they intended to leave their organization (26 percent versus 34 percent);

- six percentage points more likely to report they were held accountable for achieving results ( 87 percent versus 81 percent);

- 13 percentage points more likely to say they have a real opportunity to improve their skills in their organization ( 71 percent versus 58 percent);

- seven percentage points more likely to say their co-workers share knowledge ( 77 percent versus 70 percent); and

- eight percentage points more likely to say their talents are used well in the workplace (64 percent versus 56 percent).

There was no difference between those allowed and those not allowed to telework for those saying that their workload is unreasonable (25 percent in both cases).

\section{Summary of organizational outcomes}

Table 3.8 summarizes the most common positive, neutral and/or negative effects of telework on organizational performance. As in the previous section, much depends on how it is executed. These effects have been derived from a wide range of studies that have been catalogued by the researchers and from the researchers' own client work. ${ }^{52}$ The major factors that influence outcomes are reviewed later in this chapter. Subgroup data is not available. Please refer to the notes following Table 3.8 for further details.

\section{Effects of Telework on Worker Well-Being and Work-Life Fit or Balance}

The majority of research suggests that while some teleworkers in the US report stress from the feeling of being constantly 'on' and/or not being able to turn work off at the end of the day, ${ }^{53}$ the impact on 'work-life fit' - a 
Table 3.8 Selected effects of telework on organizational performance

\begin{tabular}{|c|c|c|c|c|}
\hline Effect & Positive & Neutral & Negative & Notes \\
\hline Productivity & $\mathrm{x}$ & $\mathrm{x}$ & & 1 \\
\hline Performance & $\mathrm{x}$ & $\mathrm{x}$ & & 1 \\
\hline Absenteeism & $\mathrm{x}$ & & & \\
\hline Attraction & $\mathrm{x}$ & & & \\
\hline Retention & $\mathrm{x}$ & & & \\
\hline Real estate costs & $\mathrm{x}$ & $\mathrm{x}$ & & \\
\hline Technology costs & $\mathrm{x}$ & $\mathrm{x}$ & & 2 \\
\hline Other costs & $\mathrm{x}$ & & & \\
\hline Customer service & $\mathrm{x}$ & & & \\
\hline Continuity of operations & $\mathrm{x}$ & & & \\
\hline Environmental sustainability & $\mathrm{x}$ & & & \\
\hline Organizational sustainability & $\mathrm{x}$ & & & \\
\hline Shareholder value & $\mathrm{x}$ & $\mathrm{x}$ & & \\
\hline Citizenship & $\mathrm{x}$ & & $\mathrm{x}$ & 3 \\
\hline Team dynamics & $\mathrm{x}$ & $\mathrm{x}$ & $\mathrm{x}$ & 4 \\
\hline Creativity & $\mathrm{x}$ & $\mathrm{x}$ & $\mathrm{x}$ & 5 \\
\hline Innovation & $\mathrm{x}$ & $\mathrm{x}$ & $\mathrm{x}$ & 5 \\
\hline Communications & $\mathrm{x}$ & $\mathrm{x}$ & $\mathrm{x}$ & 5 \\
\hline Meeting fatigue & $\mathrm{x}$ & & & \\
\hline Agility/resilience & $\mathrm{x}$ & & & \\
\hline Employee well-being & $\mathrm{x}$ & & & \\
\hline Efficiency & $\mathrm{x}$ & & & \\
\hline Talent pool & $\mathrm{x}$ & & & \\
\hline Globalization & $\mathrm{x}$ & & & \\
\hline Need for overstaffing & $\mathrm{x}$ & & & \\
\hline Mentoring & & $\mathrm{x}$ & $\mathrm{x}$ & 6 \\
\hline $\begin{array}{l}\text { On-boarding/new employee } \\
\text { indoctrination }\end{array}$ & & & $\mathrm{x}$ & 7 \\
\hline Diversity & $\mathrm{x}$ & & & \\
\hline Cultural integration & & $\mathrm{x}$ & $\mathrm{x}$ & 7 \\
\hline Trust & $\mathrm{x}$ & & & \\
\hline Disability accommodation & $\mathrm{x}$ & & & \\
\hline Labor pool burnout & $\mathrm{x}$ & & & \\
\hline Corporate travel & $\mathrm{x}$ & & & \\
\hline Employee engagement & $\mathrm{x}$ & & & \\
\hline Paper usage & $\mathrm{x}$ & & & \\
\hline
\end{tabular}

Notes:

1. A large majority of employers report employee productivity and performance improves with telework. Several studies indicate that this improvement is largely attributable to: working some or all of the time they would have spent commuting, feeling trusted and empowered, having fewer interruptions, being able to work when they are most productive, being able to work on days they might have otherwise called in sick and being able to use their own (often superior) technology. 


\section{Table 3.8 (continued)}

2. Research suggests that the majority of employers do not pay for all of an employee's technology. Many employees, in fact, prefer to use their own devices. Both of these factors can reduce the employer's cost of technology. Alternatively, for those organizations that are reliant on desktop versus laptop computers, that have not moved their files to the cloud, and in general have not kept pace with technology, upgrades will be essential to success. It should be noted that such upgrades should likely be made regardless of telework if the firm is to remain competitive. Some employers make the transition from desktop to laptop as part of their regular technology refresh cycle.

3. Organizations are increasing judged - by investors, potential hires and the media - by how they treat their people. Providing flexibility in where and when people work is viewed as good governance. Some US employers - particularly those in the public sector or those that are known for having poor customer service - have experienced a backlash from the public owing to the perception that if someone is, say, mowing their lawn in the afternoon, they must be slacking. Employers in these categories need to communicate the benefits of their policies to the public to fend off criticism.

4. While numerous US organizations successfully operate in an all-virtual model, with no one working in the same location, some contend that team dynamics suffer when people do not see each other physically. In general, a mix of face-to-face and virtual time works best. Proper training and technology provisioning (that is, smartphones, teleconferencing/videoconferencing and collaboration tools) are essential for maintaining team dynamics when people telework. Best-in-class employers work hard at finding new ways for virtual and on-site employees to connect.

5. The research is inconclusive on whether co-location is necessary for creativity, innovation and communications. Prior team dynamics, the type of job, whether training is provided, individual personalities, technology, levels of trust and more influence the processes.

6. Some organizations and their employees find that being in physically separate places reduces the subtle mentoring that takes place between senior and junior colleagues. This is perhaps one reason telework is more prevalent among more senior people.

7. Many organizations do not allow telework options for new employees, as it is felt on-site time is necessary for making connections, building trust and gaining a sense of the organizational culture. Those that do allow it for new employees have developed virtual strategies to accomplish the same thing. They also ensure that virtual and onsite employees are treated equally and are measured by results rather than presence.

phrase that is generally preferred in the US over 'work-life balance' - is largely seen as positive. ${ }^{54,55}$

In addition, some research suggests that telework is most beneficial when employees have some discretion over their work schedule as well as their place of work. ${ }^{56}$ Demographics, employee engagement levels, and how telework is implemented, practiced and culturally integrated also play a role in whether perceptions and outcomes regarding telework are positive or negative.

\section{Effects on Employee Health and Well-Being}

Available research indicates that telework/mobile work can reduce absenteeism, stress, presenteeism, accidents, and both short- and long-term disability. 
- The company Best Buy found that workers participating in their flexible work initiative, which includes telework, got 52 minutes more sleep each night, were more likely to go to the doctor when sick, slept better owing to reduced work-life conflict, were less stressed and reported better overall health. ${ }^{57}$

- Sixty-eight percent of human resource professionals felt that flexible work arrangements improved employee quality of life and 25 percent said it had a somewhat positive impact. ${ }^{58}$

- Human resource professionals felt that flexible work arrangements have a somewhat positive or positive impact on absenteeism (70 percent) and employee health and wellness (58 percent). ${ }^{59}$

- Thirty-two percent of human resource professionals report decreased absenteeism among teleworkers. Only 5 percent said it increased absenteeism. ${ }^{60}$

A synthesis of hundreds of studies by the authors, as well as the authors' own client work, suggests that telework can also have a positive impact on employee health and well-being because of: ${ }^{61}$

- the ability to return to work more quickly after medical events (by working from home);

- less worry about loved ones at home (in particular those with eldercare responsibilities);

- more time for family, fitness, friends and self;

- reduced stress from not commuting;

- greater empowerment due to feeling trusted and having control over one's time;

- reduced work-life conflict;

- reduced exposure to sick co-workers;

- less stress from office distractions;

- reduced risk of traffic accidents;

- reduced exposure to occupational hazards and environmental toxins;

- increased satisfaction owing to greater productivity;

- comfort in one's own surroundings (plants, pictures and pets);

- increased sleep;

- ability to work when they are most effective (when time flexibility is allowed); and

- escape from office politics.

However, telework is not without potential negative health and wellness outcomes. In particular, research shows that some employees: ${ }^{62}$ 
- suffer stress and burnout from the feeling they are expected to be available outside of regular hours, regardless of whether they are actually working;

- feel frustration over unclear boundaries between work and life;

- feel isolated and disconnected from their colleagues (primarily among those who telework all the time);

- feel they are left out of the loop in important communications;

- have difficulty turning work off at the end of the day;

- absent the social cues from co-workers, find they are less likely to take breaks or lunches;

- fear being passed over for projects or having reduced opportunity for advancement;

- feel frustrated when family and friends expect them to accomplish more home-related work (that is, laundry, preparing dinner, running errands, and so on) because 'they are not really working';

- sit for long periods without moving;

- have a greater temptation to overeat, oversleep, or overwork, particularly those with '-holic' tendencies to begin with;

- feel frustrated that they do not have the self-discipline to stay productive;

- tend to work while sick; and

- suffer repetitive stress injuries due to poor ergonomics.

\section{Effects on work-life conflict and stress}

Researchers from Brigham Young University analyzed data from 24436 IBM employees in 75 countries (including the US) to identify the point at which a quarter of them reported that work interfered with personal and family life. ${ }^{63}$

- For office workers on a regular schedule working at the employer's premises, the breaking point was 38 hours per week. Given a flexible schedule based on their individual needs and the option to telecommute, employees were able to work 57 hours per week before experiencing such work-life conflict.

- The author of that report stressed that it is the combination of telecommuting and a flexible schedule that reduces work-life conflict; that is, the teleworker needs to have the ability to set their own work schedule (that is, working time autonomy), rather than being required to work a normal office schedule.

Accenture's global research of 4100 US business executives found that technology plays a role in achieving work-life balance, but at the same 
time, survey respondents expressed mixed feelings about its impact on their personal lives. ${ }^{64}$

- More than three-quarters (77 percent) agreed that technology enabled them to be more flexible with their schedules, and 80 percent reported that having flexibility in their work schedule was extremely or very important to their work-life balance. Yet 70 percent also said that technology brings work into their personal lives by blurring the boundaries between work and personal life.

- Three-quarters (75 percent) of respondents reported they work frequently or occasionally during paid time off, generally checking email, catching up on work, working with no distractions and participating in conference calls (cited by 71 percent, 44 percent, 35 percent and 30 percent, respectively). At the same time, 40 percent consider themselves workaholics.

- More than half (52 percent) said they have turned down a job owing to concerns about its impact on work-life balance. Work-life balance topped respondents' definitions of career success, ahead of money, recognition and autonomy (cited by 56 percent, 46 percent, 42 percent and 42 percent, respectively).

A 2011 Ipsos special report on telecommuting showed that 78 percent of US Federal Government employees agreed (49 percent) or strongly agreed (29 percent) that employees who telecommute are better able to achieve balance between work and family. Forty-eight percent of respondents said telework actually creates more work-family conflict because it reduces the boundaries between work and family life. ${ }^{65}$ While these findings are seemingly contradictory, because of the benefits of telework a teleworker may feel better able to balance work and family even in the face of increased conflict.

Research by PGi in 2015 found 65 percent of US workers would like to work remotely. A frequency of one day a week was favored by 50 percent of respondents, and two to three days a week was cited by 46 percent of respondents. The top motives were reducing the commute and improving work-life balance. ${ }^{66}$

Research by Pew showed that 51 percent of office workers and 19 percent of non-office workers say digital tools allow them more flexibility in the hours they work. Also, 76 percent of Americans view the Internet as a good thing, 15 percent view it as a bad thing and 8 percent say it is some of both. ${ }^{67}$ These numbers vary by as much as 8 percentage points across demographics.

In addition, research by Gallup shows that 42 percent of US employees 
rated working remotely after business hours as 'strongly positive', 37 percent rate it as 'positive' and only 8 percent see it as negative. ${ }^{68}$

One peer-reviewed study by respected telework researchers suggests that, 'the positive effect of telework revolves around reduced work pressure and role conflict and increased autonomy'. ${ }^{69}$ Reduced time pressure because of less time spent commuting, for example; improved job clarity and better-defined communication channels (the need for which increases with telework); and greater autonomy in work-related activities were found to be the source of the positive effects. ${ }^{70}$

Ernst \& Young's 2015 Global Generations report asked millennials, Generation $\mathrm{X}$ and boomers to rate the following attributes in terms of their importance to what they seek in their job to help them better manage work and family responsibilities: ${ }^{71}$

- 45 percent, 44 percent and 33 percent, respectively, said telework three to five days a week;

- 50 percent, 48 percent and 38 percent, respectively, said they would like to telework one to two days a week;

- 71 percent, 73 percent and 69 percent, respectively, said the ability to work flexibly informally as needed; and

- 74 percent, 76 percent and 71 percent, respectively, said working with colleagues and supervisors who supported their efforts to work flexibly and meet both my personal and professional goals.

A US Federal Government study found 87 percent of routine government teleworkers felt telework had a positive impact on their ability to balance their work and non-work lives. Only 1 percent said it had a negative impact. ${ }^{72}$

Research by Gallup shows a positive correlation occurs between the frequency of distance work and current and future life satisfaction (which Gallup names 'thriving'). Sixty-three percent of those who work remotely seven or more hours a week say that they are thriving, compared with just 52 percent of those who never work remotely. ${ }^{73}$

Surprisingly, Gallup research even shows a positive correlation between frequently checking email outside of work and how employees rate their life satisfaction. Sixty-three percent of those who check email outside of working hours with the greatest frequency report 'thriving' compared to 54 percent of those who never do so. ${ }^{74}$

Nonetheless, in spite of these positive correlations, Gallup research also shows that both distance work and frequently checking email outside work increase employee stress. Forty-eight percent of those who frequently checked email outside of normal hours and 47 percent of those who worked remotely seven or more hours a week reported experiencing a lot 
of stress compared to 36 percent of those who never did so (36 percent and 37 percent, respectively). ${ }^{75}$

A 2012 peer-reviewed study found that the primary negative effects of telework are role ambiguity and reduced support and feedback. The report suggests these effects likely result from reduced communications, the absence of facial and other body cues during conversation, and poor communication generally. ${ }^{76}$

In a 2014 article published in the Harvard Business Review online blog, Gallup cautions employers to avoid 'jumping the gun' about polices regarding use of technology outside of normal working hours. Instead, they recommend developing workplace programs and practices aimed at increasing employee engagement with the organization ${ }^{77}$ Thirty-four percent of engaged employees whose employer expected them to check after-hours emails and 30 percent of those whose employers did not expect them to do so reported stress the previous day. By contrast, 54 percent of employees who were not engaged and 56 percent of those disengaged whose employers expected them to check emails after hours reported stress. Among those employees whose employer did not expect their employees to check emails after hours, 39 percent of those who were not engaged and 53 percent of those who were disengaged reported stress the prior day.

Gallup's work is not intended to suggest that employees not take vacations or be allowed to work long hours. The need for downtime is well documented. Gallup is merely reporting what the research shows regarding the link between engagement and employee attitudes towards mobile technology and vacation usage (among others).

\section{Best Practices for Successful Outcomes from Telework}

How telework programs are implemented and managed can have a big impact on individual and organizational success. Essential best practices include:

- unwavering commitment from senior leaders;

- change management to precede the initiative;

- a commitment to training;

- a culture of trust; and

- management by results, not presence.

Beyond those 'must haves', teleworkers are most successful when: ${ }^{78}$

- employees choose to work remotely, rather than it being a requirement;

- employees have the tools and technology they need to be productive; 
- employees receive training in technology use;

- employees receive training in remote work;

- employees are measured on results;

- employees are able to shift their working hours around personal needs;

- employees work a mix of on-site and off-site time;

- employees have access to technical support;

- remote employees are provided on-site space as needed;

- solutions are put in place to ensure that teleworkers and nonteleworkers are treated equally;

- teleworkers and non-teleworkers receive training to ensure that communication and collaboration does not suffer;

- co-workers are supportive;

- the manager is in favor of remote work;

- the manager supports work-life fit;

- the manager has worked or does work remotely;

- the manager has received training in managing remote employees;

- managers and employees have a clear understanding of expectations;

- managers and co-workers set and respect employee downtime;

- the organization determines who can and cannot work remotely in a transparent, fair and consistent way;

- the organization's leaders support remote work;

- the organization has a culture of workplace flexibility;

- the organization has a culture of trust;

- the organization provides opportunities for remote workers to engage, face to face, with co-workers on an occasional basis; and

- the organization provisions teleworkers and non-teleworkers with communications and collaboration tools and training to enable seamless interaction and access.

In addition, strategies that have been shown to help teleworkers manage work-life boundaries include: ${ }^{79}$

- having a separate office that they can leave at the end of the day;

- occasionally working from a third place;

- setting alarms or using apps to remind them when to quit; and

- establishing routines around start times, end times and break times.

The organizational impacts of telework are most positive when: ${ }^{80}$

- cross-functional teams are involved in establishing a telework program - as a minimum that should include representatives from 
human resources, real estate, information technology, risk management, sustainability and communications;

- managers, teleworkers and non-teleworker receive appropriate training;

- change management programs accompany the introduction of telework programs;

- employees are provisioned with appropriate technology and adequately trained in its use;

- home office ergonomics and safety are addressed;

- there is a clear understanding of working hours/days, availability, and performance measurement;

- managers and co-workers are supportive of telework;

- senior management clearly supports telework;

- effective virtual communications technology is made available;

- checks are put in place to ensure that the treatment of teleworkers is consistent with that of non-teleworkers when it comes to promotions, provisioning and work assignments;

- policies and practices are established and applied consistently; and

- teleworkers are selected appropriately.

\section{POLICY RESPONSES TO TELEWORK}

A variety of federal, state and sectoral policies have impacted or are soon likely to impact the incidence and nature of telework in the US.

\section{US Federal Government Law Regarding Telework among Federal Employees}

Since 2000, US Federal law has required that every US government employee work from home to the maximum extent possible. ${ }^{81}$ The original impetus was fear of a government shutdown owing to the avian flu pandemic.

Since that time, acts of terrorism, extreme weather events and other pandemic threats have repeatedly reminded government leaders of the need for telework as a cornerstone in its continuity of operations strategy (for example, during crisis periods such as the avian flu pandemic). While numerous congressional bills aimed at expanding and enforcing the 2000 mandate have been proposed, little progress was being made toward federal telework adoption.

In 2010 then-President Obama, referring to himself as the 'Teleworker in Chief' (because he worked at his home, the White House), lobbied hard 
for more telework for federal government employees. He also moved the conversation about telework beyond its previous focus on continuity of operations and framed it as a strategy for reducing work-life conflict, attracting and retaining talent, and measuring people by results rather than presence.

In December of 2010, the Telework Enhancement Act (TEA) passed both houses of Congress with bipartisan support and was signed into law by the President. While most of the enforcement aspects of the Act, as well as specific funding for Federal Government agency implementation, were lost during Congressional debates, the law requires US Federal Government agencies to: 82

- establish a policy under which eligible employees would be allowed to telework;

- designate a Telework Managing Officer;

- determine eligibility of employees and notify them of their eligibility status;

- designate a senior manager to coordinate each agency's telework program;

- require a written agreement between an agency manager and each of his or her employees authorized to telework;

- develop and implement telework training programs for managers and employees;

- ensure that interactive training be provided to eligible employees and their managers and that the training be successfully completed prior to entering into a telework agreement; and

- adopt telework as a part of the agency's Continuity of Operations Plan.

The US Office of Personnel Management's (OPM's) Director could not have been clearer about his and the Obama administration's support for telework in the agency's annual report on the status of telework to Congress: ${ }^{83}$

I believe telework must be implemented with a focus on accountability. As the President said at his White House Forum on Workplace Flexibility last March, 'It's about attracting and retaining top talent in the federal workforce and empowering them to do their jobs, and judging their success by the results that they get - not by how many meetings they attend, or how much face-time they $\log$... Presenteeism, the practice of sitting at one's desk without working, can be just as problematic as absenteeism. I am an adamant supporter of telework because workers in an effective telework program can only be judged by their results. Those who can't perform and can't improve can't hide behind their 
desks. It is up to management to give our employees clear direction and support, and then trust them to deliver.

While the TEA and OPM offered agencies guidance for the development of their telework programs, each is left to develop its own policies, training, and procedures.

Approximately 36 percent of federal employees are members of a labor union, ${ }^{84}$ and agencies were similarly left on their own to negotiate telework issues with their labor unions. Union receptivity has been mixed. The issues have centered on:

- the physical burden of carrying a laptop;

- the issue of lost paid time off during unexpected office shutdowns (such as snow days and floods);

- ambiguity over who can and who cannot telework;

- ensuring privacy;

- the expectation of always being available;

- issues related to overtime and travel pay; and

- employees being expected to use/maintain their own technology.

The most recent annual report to Congress (2013 reporting on 2012 results) showed the following rate of agency compliance toward the mandates set by the TEA (see above). ${ }^{85}$

- Establish a policy: 76 percent of agencies.

- Designate a Telework Managing Officer: 98 percent of agencies.

- Determine eligibility of employees: 47 percent eligible; notify them of their eligibility status: 88 percent.

- Designate a senior manager to coordinate the agency's telework program: 97 percent.

- Establish a written agreement between an agency manager and each of his or her employees authorized to telework: of the 91 percent of agencies that maintained such records reported 267227 signed agreements in place (21 percent of eligible employees).

- Ensure that an interactive training program is completed by potential teleworkers: compliance not discernable from available reports.

- Adopt telework as a part of the agency's Continuity of Operations Plan: 46 percent.

Since the signing of the TEA, telework participation of one day a week or more has grown from 4 percent of federal employees in 2011 to 14 percent in $2014 .{ }^{86}$ 
An in-depth analysis of the obstacles faced by US Federal Government agencies in furthering telework is available in a White Paper produced by the authors of this report. It is entitled Federal Telework: Obstacles and Opportunities and is based on surveys and interviews of federal leaders in 2013. The primary obstacles centered on issues of accountability, culture, training and technology provisioning. ${ }^{87}$

\section{State and Local Initiatives Regarding Telework}

State and local telework initiatives have been largely focused on the reduction of commuter travel in areas with heavy traffic congestion. A few have been aimed at creating employment in areas where industry shifts have caused high levels of unemployment (for example, coal towns and steel towns). In cities with the heaviest pollution, employers can avoid substantial financial penalties by reducing employee commuter travel.

States including Virginia, Georgia, Washington, Minnesota, Texas, California, Connecticut and a handful others have, at some time, implemented advocacy, training and, even, grant programs aimed at encouraging private and public sector adoption of telework. Most of the funding for those initiatives has come from US Department of Transportation state allocations. Reductions in federal, and thus state, funding have forced the closure of many of these programs in recent years.

\section{Other Federal and State Existing and Pending Laws that May Impact Telework}

Both US Federal Government and state governments in the US set regulations designed to protect employees' well-being. Some are considering new laws and regulations that may directly or indirectly impact organizations that offer telework.

\section{US Federal Government and state government rules concerning overtime pay}

While neither Federal nor various US state governments currently have specific regulations regarding use of ICTs away from the employer's premises or beyond normal working hours, some governments have shown, or are beginning to show, some interest in the topic, primarily as it relates to overtime payments for supplemental telework (that is, telework that increases working hours beyond the legal limits).

Currently, US federal law requires that most non-exempt employees be paid overtime rates for work conducted in excess of 40 hours a week. Some states, such as California, have extended this right to include many 
exempt employees. ${ }^{88}$ Under federal law, any work performed beyond the established weekly legal limit is compensable for non-exempt employees, generally at a rate that is a 50 percent increase over an employee's base rate of pay. In practice, however, someone who occasionally answers emails after hours rarely reports that time as part of their working hours, but not everyone is satisfied with this situation.

- In 2009, several sales personnel at T-Mobile USA filed suit against their employer for allegedly requiring them to provide a mobile number on their business cards so customers could reach them at all times. The company settled out of court for an undisclosed sum. ${ }^{89}$

- In an individual law suit brought in 2015, the US Court of Appeals ruled that, provided the employer makes timesheets or the equivalent available to the employee, the burden of tracking workers' working time for work performed remotely is the responsibility of the employee. ${ }^{90}$

Aside from the T-Mobile company case, most of the legal actions to date have been treated as individual cases rather than class action suits. 'As a result,' says the author of a 2015 Wall Street Journal article, 'they haven't proceeded as precedent-setting actions involving a large group of workers'. ${ }^{91}$

\section{Occupational health and safety policies related to telework}

Employees who work remotely are subject to the same occupational health and safety standards as any employee. Employers ensure compliance with a variety of methods including home audits, self-certification, photo audits and/or formal telework policies.

Some employers are building wellness/well-being into their corporate strategies. Their primary drivers include: being an employer of choice, reducing healthcare costs, reducing absenteeism/presenteeism, increasing engagement, reducing work-life conflict and improving employee well-being.

The most common wellness programs involve incentivizing employees to utilize full vacation time, developing workplaces and work practices that focus on employee well-being, seeking an evidence-based office environment standard that optimizes the health and well-being of its employees (WELL ${ }^{\mathrm{TM}}$ certification) ${ }^{92}$ for their buildings, providing areas where employees can rest and recover, offering stress-management training, offering wellness programs, providing eldercare assistance, offering workplace flexibility training for managers to recognize signs of burnout, and so on. 


\section{Tax and labor law implications of telework}

State employment laws and even some local employment laws (such as those that relate to overtime, working hours, employee safety, employee benefits, travel reimbursement and employee classification) as well as employment taxes often differ from federal laws. A number of states and local governments are aggressively pursuing what they see as potentially lost tax revenues owing to remote work.

Since ensuring compliance is extremely difficult for employers who may not even know where their people are working, some have resorted to closing down email servers outside of regular business hours. The California Chamber of Commerce's Employment Law blog, for example, suggests that employers implement policies and practices such as: prohibiting afterhours work among non-exempt employees without prior approval; not issuing smartphones or other portable electronic devices to non-exempt employees; and blocking their after-hours access to company servers. ${ }^{93}$ The results of these actions may potentially reduce flexibility for employees to work where and when they choose.

\section{Private Sector Initiatives Regarding Telework}

According to the Society for Human Resource Management (SHRM), approximately one-fifth of organizations (21 percent) have a formal policy that regulates wireless communication device use outside of normal working hours, while roughly one-quarter of organizations ( 26 percent) have an informal policy. ${ }^{94}$

Of those organizations that have informal wireless communication device usage policies in place, approximately four out of five (81 percent) express their limitations of wireless communication device use to employees directly through supervisors or managers. Of the organizations that do not have a formal or informal policy on wireless communications device usage, the large majority ( 87 percent) allows their employees to set their own limits on the use of wireless communication devices for work purposes outside of normal working hours.

There are some interesting examples of organizational policies as regards telework.

- Pomona College in California instructed employees that they were not to use email after business hours. This was in response to a State of California law making all employees eligible for overtime pay. ${ }^{95}$

- Motivated by improving employee work-life balance, Vynamic, a small Pennsylvania-based healthcare industry consultancy, started shutting down access to email on weekends and from 10 p.m. to 
6 a.m. on weekdays. The company says the move has increased productivity and employee happiness because employees are better rested. ${ }^{96}$

- Van Meter, an electronic parts distributor in Iowa, put a stop to non-essential work-related emails after 5 p.m. and before 7 a.m. on weekdays and altogether during employee vacations. The purpose of the move was to improve work-life balance. ${ }^{97}$

- In an effort to reduce employee stress, Edelman, a Canadian-based public relations firm, strongly discourages emails from 7 p.m. to 7 a.m. ${ }^{98}$

- When a team of consultants at Boston Consulting Group began organizing 'predictable time off' and a 'no messaging zone' during their off-time, their total hours dropped by 11 percent without any diminishment in work output. Seventy-two percent of employees participating in the program said they were satisfied with their job compared with only 49 percent of those not participating; 54 percent said they were satisfied with their work-life balance (compared with 38 percent); and 51 percent said they were excited to go to work the next morning (compared with 27 percent). ${ }^{99}$

Finally, it should be noted that legal pressure from employees and employee groups regarding after-hours work is increasing, as discussed in previous sections.

\section{CONCLUSIONS AND RECOMMENDATIONS FOR ACTION}

The US is behind many European Union countries in establishing and enforcing laws that pertain to employee well-being. It was not until 1971 that the Occupational Safety and Health Administration (OSHA) under the US Department of Labor (DOL) was established to ensure safe and healthful working conditions by setting and enforcing safety standards. United States federal, state and local government actions taken to date have primarily focused on the extent to which telework use violates tax and labor laws.

Public and private sector employer actions have been largely focused on:

- avoiding fines and legal action brought by labor unions and/or workers;

- attracting and retaining talent/organizational sustainability;

- creating a public perception of good citizenship; 
- ensuring that workers have an adequate amount of time off because they understand the benefits of downtime for health, productivity, employee engagement, and so on; and

- expressing a genuine concern for their workforce.

While employees are working differently than they did a decade ago, the numbers suggest that they are not necessarily working substantially more hours. There will always be workaholics, that is, individuals who for a variety of reasons choose to work long hours, and long hours are also part of some companies' business models (for example, major law firms). Some employees work long hours because of work overload, but others are happy to do so because they are truly engaged in what they do.

On balance, teleworkers in the US report that being able to work when and where they want reduces work-life conflict, improves their overall work-life balance and offers a variety of other benefits. While some regular teleworkers work longer hours than their counterparts who always work in the office, their leisure time is nearly the same thanks to reduced commuting time - with the added benefit of a reduction of commutingrelated stress.

Despite some drawbacks, a substantial majority (79 percent) of American employees (aged 35-54 years) want to telework, ${ }^{100}$ and the overall benefits of telework to both employers and employees have been documented in this chapter. The key to making telework sustainable for both lies in how it is implemented. In particular, manager and employee training for telework are crucial. With a mutual understanding of expectations, good practices, communications protocols and the tools required to get the job done, telework can offer a triple win for people, planet and profit.

\section{NOTES}

1. These figures are the authors' own calculations. The authors are Kate Lister and Tom Harnish of Global Workplace Analytics. The figures are based on data from the following data sources: the US Census Bureau, the General Social Survey, the Bureau of Labor Statistics and Ipsos.

2. The Dieringer Research Group (2009), 'Telework trendlines 2009', report, WorldatWork, Scottsdale, AZ; US Office of Personnel Management (2013), '2013 status of telework in federal government', US Office of Personnel Management, Washington, DC.

3. Lister, K. and Harnish, T. (2011), 'State of telework in the United States: how individuals, business and government benefit', Telework Research Network, Global Workplace Analytics, Carlsbad, CA.

4. Matos, K., Galinsky, E. and Bond, J.T. (2014), '2014 National Study of Employers', Families and Work Institute and the Society for Human Resource Management, Washington, DC. 
5. These figures are the authors' own calculations based on data from the American Community Survey, 2014, US Census Bureau, Suitland, MD, accessed 25 June 2019 at https://www.census.gov/programs-surveys/acs/data.html.

6. These figures are the authors' own calculations based on data from the American Community Survey, 2013, US Census Bureau, Suitland, MD, accessed 25 June 2019 at https://www.census.gov/programs-surveys/acs/data.html.

7. Lonnie Golden, Professor of Economics and Labor-Employment Relations at Penn State University, Abington College, extracted data from the GSS for this chapter. His analysis showed no significant differences among the various populations regarding the data included in this chapter.

8. US General Social Survey, NORC at the University of Chicago, 2014, accessed 25 June 2019 at https://gss.norc.org/Get-The-Data.

9. Ipsos Global@dvisor (2011), 'Telecommuting: citizens in 24 countries assess working remotely for a total global perspective', Ipsos, accessed 14 August 2016 at https://www. ipsos.com/sites/default/ files/news_and_polls/2012-01/5486-ppt.pdf.

10. Federal Employee Viewpoint Survey 2014, US Office of Personnel Management, Washington, DC.

11. These figures are the authors' own calculations based on data from the American Time Use Survey 2014, in the American Community Survey 2014, US Census Bureau, Suitland, MD, accessed 25 June 2019 at https://www.census.gov/programs-surveys/acs/ data.html.

12. Jack Nilles coined the terms telework and telecommuting in the mid-1970s to better represent what he originally called the 'Telecommunications-Transportation Tradeoff'. (J.M. Nilles, 1976, Telecommunications-Transportation Tradeoff: Options for Tomorrow, New York: John Wiley \& Sons.) While the two terms are often used interchangeably, 'telecommuting' is actually a subset of telework. Nilles defines 'telework' as any form of substitution of information technologies (such as telecommunications and/or computers) for normal work-related travel; moving the work to the workers instead of moving the workers to the work. He defines 'telecommuting' as the portion of telework that applies to the daily commute to and from work; a primary source of traffic congestion, air pollution, and lost productivity (http://jala.com/history.php, accessed 25 June 2019).

13. Ernst \& Young (2015), 'Global generations: a global study on work-life challenges across generations', EYG no. KK1088, Ernest and Young Global Management (EYGM).

14. WorldatWork (2015), 'Total rewards and employee well-being practices: a report by WorldatWork underwritten by HealthMine', WorldatWork, Scottsdale, AZ. WorldatWork is a nonprofit professional association engaged in the cultivation of successful compensation and total rewards strategies.

15. Accenture (2013), 'Defining success: 2013 global research results', accessed 26 July 2017 at www.accenture.com/IWD.

16. Ernst \& Young (2015), 'Global generations: a global study on work-life challenges across generations', EYG no. KK1088, Ernest and Young Global Management (EYGM) Limited.

17. Golden, L., Lambert, S., Henly, J. and Wiens-Tuers, B. (2011), 'Working time in the employment relationship: perceived control and work-life balance', in K. Townsend and A. Wilkinson (eds), The Edward Elgar Research Handbook on Work and Employment Relations, Cheltenham, UK and Northampton, MA, USA: Edward Elgar, pp. 188-211.

18. Purcell, K. and Rainie, L. (2014), 'Email and the Internet are the dominant technological tools in American workplaces', Pew Research Center, accessed 20June 2017 at https:// www.pewinternet.org/2014/12/30/email-and-the-internet-are-the-dominant-technologi cal-tools-in-american-workplaces/.

19. The Dieringer Research Group (2009), 'Telework trendlines 2009', report, WorldatWork, Scottsdale, AZ.

20. These figures are the authors' own calculations based on data from the Federal 
Employee Viewpoint Survey, 2014, US Office of Personnel Management, Washington, DC.

21. Ernst \& Young (2015), 'Global generations: a global study on work-life challenges across generations', EYG no. KK1088, Ernest and Young Global Management (EYGM) Limited.

22. These figures are the authors' own calculations based on data from the US General Social Survey, 2014, NORC at the University of Chicago.

23. These figures are the authors' own calculations based on data from the Federal Employee Viewpoint Survey, 2014, US Office of Personnel Management, Washington, DC.

24. These figures are the authors' own calculations based on data from the Federal Employee Viewpoint Survey, 2014, US Office of Personnel Management, Washington, DC.

25. Lister, K. and Harnish, T. (2017), '2017 State of telecommuting in the US employee workforce, Global Workplace Analytics and FlexJobs, accessed 22 June 2017 at http:// globalworkplaceanalytics.com/whitepapers.

26. These figures are the authors' own calculations based on data from Global Workplace Analytics analysis of the US American Community Survey, 2015 (US Census Bureau, Washington, DC).

27. These figures are the authors' own calculations based on data from Global Workplace Analytics analysis of the US American Community Survey, 2015 (US Census Bureau, Washington, DC).

28. These figures are the authors' own calculations based on data from Global Workplace Analytics analysis of the US American Community Survey, 2015 (US Census Bureau, Washington, DC).

29. These figures are the authors' own calculations based on data from Global Workplace Analytics analysis of the US American Community Survey, 2015 (US Census Bureau, Washington, DC).

30. These figures are the authors' own calculations based on data from Global Workplace Analytics analysis of the US American Community Survey, 2015 (US Census Bureau, Washington, DC).

31. These figures are the authors' own calculations based on data from Global Workplace Analytics analysis of the US American Community Survey, 2015 (US Census Bureau, Washington, DC).

32. These figures are the authors' own calculations based on data from Global Workplace Analytics analysis of the US American Community Survey, 2015 (US Census Bureau, Washington, DC).

33. Ahmade, R., Brand, J., Creighton, J., Dirks, G., Hood, C., Nagy, G., et al. (2013), 'New WOW alternative workplace strategies benchmarking study', 1 November, New Ways of Working, unpublished report.

34. These figures are the authors' own calculations based on data from the US Census Bureau, the General Social Survey, the Bureau of Labor Statistics and Ipsos.

35. Based on data from the American Community Survey, 2013, US Census Bureau, Suitland, MD, accessed 25 June 2019 at https://www.census.gov/programs-surveys/acs/ data.html.

36. 2017 was the first year that this question was asked.

37. Gallup, Inc. (2017), 'Work and workplace', March, accessed 6 February 2018 at http:// news.gallup.com/poll/1720/work-work-place.aspx.

38. Gallup, Inc. (2014), 'Should employers ban email after work hours?', September, accessed 6 January 2017 at https://www.gallup.com/workplace/236519/employers-banemail-work-hours.aspx.

39. Ibid.

40. The following papers are available at http://globalworkplaceanalytics.com/whitepapers: Lister, K. and Harnish, T. (2011), 'State of telework in the US', Global Workplace Analytics, Carlsbad, CA, online 8 November 2011; Lister, K. and Harnish, T. (2010), 'Telecommuting benefits: the bottom line', Global Workplace Analytics, Carlsbad, 
CA, online 10 August 2010; Lister, K. and Harnish, T. (2011), 'The bottom line on telework: California government workforce', Global Workplace Analytics, Carlsbad, CA, online 8 March 2012; Lister, K. and Harnish, T. (2012), 'Federal telework obstacles and opportunities', Global Workplace Analytics, Carlsbad, CA, online 10 December 2013; Lister, K. and Harnish, T. (2011), 'The bottom line on telework for the Thurston Region state and local government', Global Workplace Analytics, Carlsbad, CA, online 14 August 2014; Lister, K. and Harnish, T. (2013), 'Federal telework return on taxpayer investment', Global Workplace Analytics, Carlsbad, CA, online 30 May 2015; Lister, K. and Harnish, T. (2011), 'The shifting nature of work in the UK', Global Workplace Analytics, Carlsbad, CA, online 9 June 2015; Lister, K. and Harnish, T. (2010), 'Results based management: the key to unlocking talent and increasing productivity', Global Workplace Analytics, Carlsbad, CA, online 30 May 2015; Lister, K. and Harnish, T. (2010), 'Workshift Canada: the bottom line on telework', Global Workplace Analytics, Carlsbad, CA, online 1 August 2012.

41. Lister, K. and Harnish, T. (2010), 'Telecommuting benefits: the bottom line', Global Workplace Analytics, Carlsbad, CA, online 10 August 2010, accessed 25 June 2019 at http://globalworkplaceanalytics.com/whitepapers.

42. Matos, K. and Galinsky, E. (2012), '2012 national study of employers', Families and Work Institute and Society for Human Resource Management, Washington, DC.

43. Golden, L., Lambert, S. and Henly, J. (2013), 'Work schedule flexibility: a contributor to employee happiness?', Journal of Social Research and Policy, 4 (2), 107-35.

44. WorldatWork (2013), 'Survey on workplace flexibility 2013', WorldatWork, Scottsdale, $\mathrm{AZ}$.

45. Ipsos Global @dvisor (2011), 'Telecommuting: citizens in 24 countries assess working remotely for a total global perspective', Ipsos, accessed 14 August 2016 at https://www. ipsos.com/sites/default/ files/news_and_polls/2012-01/5486-ppt.pdf.

46. Lister, K. and Harnish, T. (2011), 'The bottom line on telework for the Thurston Region state and local government', Global Workplace Analytics, Carlsbad, CA, online 14 August 2014, accessed 25 June 2019 at http://globalworkplaceanalytics.com/ whitepapers.

47. Presenteeism is defined in the US as meaning present at work but not performing one's best, not simply being physically present in the office.

48. Weinert, C., Maier, C. and Laumer, S. (2015), 'Why are teleworkers stressed? An empirical analysis of the causes of telework-enabled stress', in O. Thomas and F. Teuteberg (eds), Proceedings of the 12th International Conference on Wirtschaftsinformatik, Osnabrück, pp. 1407-21.

49. US Office of Personnel Management (2014), Federal Employee Viewpoint Survey Results, accessed 18 January 2017 at https://www.opm.gov/policy-data-oversight/data -analysis-documentation/employee-surveys/results/2014-employee-survey-results/.

50. Ibid.

51. US Office of Personnel Management (2013), '2013 Status of telework in government - report to Congress', US Office of Personnel Management, Washington, DC.

52. Lister, K. and Harnish, T. (2011), 'State of telework in the US', Global Workplace Analytics, Carlsbad, CA, online 8 November 2011; Lister, K. and Harnish, T. (2010), 'Telecommuting benefits: the bottom line', Global Workplace Analytics, Carlsbad, CA, online 10 August 2010; Lister, K. and Harnish, T. (2011), 'The bottom line on telework: California government workforce', Global Workplace Analytics, Carlsbad, CA, online 8 March 2012; Lister, K. and Harnish, T. (2012), 'Federal telework obstacles and opportunities', Global Workplace Analytics, Carlsbad, CA, online 10 December 2013; Lister, K. and Harnish, T. (2011), 'The bottom line on telework for the Thurston Region state and local government', Global Workplace Analytics, Carlsbad, CA, online 14 August 2014; Lister, K. and Harnish, T. (2013), 'Federal telework return on taxpayer investment', Global Workplace Analytics, Carlsbad, CA, online 30 May 2015; Lister, K. and Harnish, T. (2011), 'The shifting nature of work in the UK', Global Workplace Analytics, Carlsbad, CA, online 9 June 2015; Lister, K. and Harnish, 
T. (2010), 'Results based management: the key to unlocking talent and increasing productivity', Global Workplace Analytics, Carlsbad, CA, online 30 May 2015; Lister, K. and Harnish, T. (2010), 'Workshift Canada: the bottom line on telework', Global Workplace Analytics, Carlsbad, CA, online 1 August 2012. These papers accessed 25 June 2019 at http://globalworkplaceanalytics.com/whitepapers.

53. Sodexo (2014), '2014 workplace trends report', accessed 15 February 2015 at http:// sodexousa.com/usen/media/press-releases/2014/news-2014-workplace-trends.aspx.

54. Society for Human Resource Management (2014), '2014 workplace flexibility survey: overview of flexible work arrangements', Society for Human Resource Management, accessed 4 June 2017 at https://www.shrm.org/hr-today/trends-and-forecasting/researchand-surveys/pages/2014-workplace-flexibility-survey.aspx.

55. Golden, L., J.R. Henly and S. Lambert (2013), 'Work schedule flexibility: a contributor to happiness?', Journal of Social Research \& Policy, 4 (2), 107-35.

56. Golden, L., Lambert, S., Henly, J. and Wiens-Tuers, B. (2011), 'Working time in the employment relationship: perceived control and work-life balance', in K. Townsend and A. Wilkinson (eds), The Edward Elgar Research Handbook on Work and Employee Relations, Cheltenham, UK and Northampton, MA, USA, pp. 188-211.

57. Moen, P., Kelly, E.L., Tranby, E. and Huang, Q. (2011), 'Changing work, changing health: can real work-time flexibility promote health behaviors and well-being', Journal of Health and Social Behavior, 54 (4), 404-29.

58. Society for Human Resource Management (2009), 'Workplace flexibility in the 21st century: meeting the needs of the changing workforce', Society for Human Resource Management, accessed 4 June 2017 at https://blog.shrm.org/sites/default/files/ reports/09-0464_Workplace_Flexibility_Survey_Report_inside_FINALonline.pdf.

59. Ibid.

60. Society for Human Resource Management (2014), '2014 workplace flexibility survey: overview of flexible work arrangements', Society for Human Resource Management, accessed 4 June 2017 at https://www.shrm.org/hr-today/trends-and-forecasting/researchand-surveys/pages/2014-workplace-flexibility-survey.aspx.

61. Lister, K. and Harnish, T. (2010), 'Telecommuting benefits: the bottom line', Global Workplace Analytics, Carlsbad, CA, accessed 10 August 2010 at http://globalwork placeanalytics.com/whitepapers; Lister, K., and Harnish, T. (2013), 'Federal telework return on taxpayer investment, federal telework return on taxpayer investment', Global Workplace Analytics, Carlsbad, CA, accessed 30 May 2015 at http://globalworkplaceana lytics.com/whitepapers; Nilles, J.M. (1998), Managing Telework: Strategies for Managing the Virtual Workforce, Hoboken, NJ: John Wiley \& Sons; Lake, A. (2013), Smart Flexibility: Moving Smart and Flexible Working from Theory to Practice, Aldershot: Gower; Clapperton, G. and P. Vanhoutte (2014), The Smarter Working Manifesto, Oxford: Sunmakers.

62. Ibid. (all).

63. Hill, E.J.; Erickson, J.J., Holmes, E.K. and Ferris, M. (2010), 'workplace flexibility, work hours, and work-life conflict: finding an extra day or two', Journal of Family Psychology, 24 (3), 349-58.

64. Accenture (2013), 'Defining success: 2013 global research results', Accenture, 1 March, accessed 14 April 2015 at www.accenture.com/IWD.

65. Ipsos Global @dvisor (2011), 'Telecommuting: citizens in 24 countries assess working remotely for a total global perspective', Ipsos, accessed 12 July 2016 at https://www. ipsos.com/sites/default/ files/news_and_polls/2012-01/5486-ppt.pdf.

66. PGi (2015), 'PGi global telework survey report', PGi, accessed 12 July 2016 at https:// www.pgi.com/resources/white-papers/2015-pgi-global-telework-survey/.

67. Fox, S. and Rainie, L. (2014), 'Part 1: how the Internet has woven itself into American life', Pew Research Center Internet and American Life Survey (Omnibus survey), Pew Research Center, accessed 3 September 2016 at https://www.pewinternet. org/2014/02/27/part-1-how-the-internet-has-woven-itself-into-american-life/.

68. Harter, J. and Agrawal, S. (2014), 'Most U.S. workers see upside to staying connected 
at work', Gallup, accessed 3 September 2016 at https://news.gallup.com/poll/168794/ workers-upside-staying-connected-work.aspx.

69. In abstract of Sardeshmukh, S.R., Sharma, D. and Golden, T.D. (2012), 'Impact of telework on exhaustion and job engagement: a job demands and job resources model', New Technology Work and Employment, 27 (3), 193-207.

70. Sardeshmukh, S.R., Sharma, D. and Golden, T.D. (2012), 'Impact of telework on exhaustion and job engagement: a job demands and job resources model', New Technology Work and Employment, 27 (3), 193-207.

71. Ernst \& Young (2015), 'Global generations: a global study on work-life challenges across generations', EYG no. KK1088, Ernest and Young Global Management $($ EYGM $)$ - based on the question: 'Please rate the following factors that would cause you to seriously consider leaving a job based on how important they are to you'.

72. US Merit Systems Protection Board (2011), 'Telework: weighing the information, determining an appropriate approach', a report to the President and the Congress of the United States by the US Merit Systems Protection Board, Washington, DC.

73. Witters, D. and Liu, D. (2014), 'Using mobile technology for work linked to higher stress', Gallup, May, accessed 6 November 2016 at https://news.gallup.com/ poll/168815/using-mobile-technology-work-linked-higher-stress.aspx.

74. Ibid.

75. Ibid.

76. Sardeshmukh, S.R., Sharma, D. and Golden, T.D. (2012), 'Impact of telework on exhaustion and job engagement: a job demands and job resources model', New Technology Work and Employment, 27 (3), 193-207.

77. Harter, J. (2014), 'Should employers ban email after work hours?', Harvard Business Review blog, August, accessed 17 December 2016 at https://hbr.org/2014/08/should-emp loyers-ban-email-after-work-hours.

78. Lister, K. and Harnish, T. (2010), 'Telecommuting benefits: the bottom line', Global Workplace Analytics, Carlsbad, CA, accessed 10 August 2010 at http://globalwork placeanalytics.com/whitepapers; Lister, K., and Harnish, T. (2013), 'Federal telework return on taxpayer investment, federal telework return on taxpayer investment', Global Workplace Analytics, Carlsbad, CA, accessed 30 May 2015 at http://globalworkplaceana lytics.com/whitepapers; Nilles, J.M. (1998), Managing Telework: Strategies for Managing the Virtual Workforce, Hoboken, NJ: John Wiley \& Sons; Lake, A. (2013), Smart Flexibility: Moving Smart and Flexible Working from Theory to Practice, Aldershot: Gower; Clapperton, G. and P. Vanhoutte (2014), The Smarter Working Manifesto, Oxford: Sunmakers.

79. Ibid. (all).

80. Ibid. (all).

81. US Office of Personnel Management (2011), 'Guide to telework in the Federal Government', US Office of Personnel Management, Washington, DC, s. 359 of Public Law 106-346.

82. US Office of Personnel Management (2011), 'Guide to telework in the Federal Government', US Office of Personnel Management, Washington, DC, s. 359 of Public Law 106-346.

83. US Office of Personnel Management (2012), '2013 Status of telework in federal government, report to the Congress', US Office of Personnel Management, Washington, DC, p. 36 .

84. US Bureau of Labor Statistics (2014), 'Union membership for annual 2013', Economic News Release, January, US Bureau of Labor Statistics, Washington, DC.

85. US Office of personnel management (2013), '2013 status of telework in federal government, report to the Congress', US Office of Personnel Management, Washington, DC.

86. US Office of Personnel Management (2014), 'Federal employee viewpoint survey results', accessed 12 July 2016 at https://www.opm.gov/policy-data-oversight/data-analysis-docu mentation/employee-surveys/results/2014-employee-survey-results/.

87. Lister, K. and Harnish, T. (2012), 'Federal telework obstacles and opportunities', 
November, Global Workplace Analytics, Carlsbad, CA, online 30 May 2015, http:// globalworkplaceanalytics.com/whitepapers.

88. The terms 'non-exempt' and 'exempt' derive from the Fair Labor Standards Act of 1938. They refer to those employees who either are eligible or are not eligible for overtime payments under the Act, respectively. The US Department of Labor establishes regulations that determine which employees are considered to be eligible for such payments, which change from time to time.

89. Weber, L. (2015), 'Can you sue the boss for making you answer late-night email?', Wall Street Journal, 20 May, accessed 1 May 2017 at https:/www.wsj.com/articles/can -you-sue-the-boss-for-making-you-answer-late-night-email-1432144188.

90. Polishuk, A. (2015), 'Timekeeping for telecommuters under the FLSA' (U.S. Fair Labor Standards Act), California Public Agency Labor and Employment blog, 26 May 2015, accessed 26 May 2015 at https://www.calpublicagencylaboremploymentblog. com/wage-and-hour-2/timekeeping-for-telecommuters-under-the-flsa/.

91. Weber, L. (2015), 'Can you sue the boss for making you answer late-night email?', Wall Street Journal, 20 May, accessed 1 May 2017 at https://www.wsj.com/articles/can -you-sue-the-boss-for-making-you-answer-late-night-email-1432144188.

92. WELL Certification is a trademarked name owned by Delos Living, New York.

93. California Chamber of Commerce (CalChamber) (2015), 'DOL taking interest in smartphones and off-the-clock work', CalChamber HRWatchdog, 28 May, accessed 28 May 2015 at https://hrwatchdog.calchamber.com/2015/05/dol-taking-interest-insmartphones-and-off-the-clock-work/.

94. Society for Human Resource Management (SHRM) Staff (2012), 'Technology and its impact on employees during non-working hours', SHRM blog, 1 August, accessed 7 August 2015 at https://blog.shrm.org/workplace/technology-and-its-impact-on-emplo yees-during-nonworking-hours.

95. Noguchi, Y. (2015), 'Amid new overtime rules, more employers might set email curfew', National Public Radio, 8 July, accessed 8 July 2015 at https:/www.npr.org/sections/ alltechconsidered/ 2015/07/08/416515537/amid-new-overtime-rules-more-employersmight-set-email-curfew.

96. Ibid.

97. Rayasam, R. (2015), 'The end of the inbox: companies that banned email', BBC, 25 March, accessed 25 March 2015 at http://www.bbc.com/capital/story/20150324-the-com panies-that-banned-email.

98. Thompson, C. (2015), 'End the tyranny of 24/7 email', New York Times, 28 August, Opinion pages, accessed 28 August 2015 at https://www.nytimes.com/2014/08/29/opinion /end-the-tyranny-of-24-7-email.html.

99. Perlow, L. (2012), 'Predictable time off: the team solution to overcoming constant work connection',FastCompanyblog,21 May, accessed 7 July2016athttps://www.fastcompany. $\mathrm{com} / 1837867 /$ predictable-time-team-solution-overcoming-constant-work-connection.

100. Burnett, J. (2018), 'Survey: workers in these cities like the option to telecommute the most', The Ladders, 13 June, accessed 14 June 2018 at https://www.theladders.com/ career-advice/survey-workers-in-these-cities-like-the-option-to-telecommute-the-most. 